\title{
Body Condition Scores and Dairy Form Evaluations as Indicators of Days Open in US Holsteins
}

\author{
C. D. Dechow, ${ }^{1}$ G. W. Rogers, ${ }^{1}$ L. Klei, ${ }^{2}$ \\ T. J. Lawlor, ${ }^{2}$ and P. M. VanRaden ${ }^{3}$ \\ ${ }^{1}$ Dept. of Animal Science, University of Tennessee, \\ 2640 Morgan Circle Dr., Knoxville 37996 \\ ${ }^{2}$ Holstein Association USA, 1 Holstein Place, \\ Brattleboro, VT 05302 \\ ${ }^{3}$ Animal Improvement Programs Laboratory, \\ Agricultural Research Service, USDA, \\ Beltsville, MD 20705-2350
}

\begin{abstract}
The objectives of this study were to estimate genetic correlations among body condition score (BCS), dairy form, milk yield, and days open in US Holsteins and investigate the potential of using BCS or dairy form evaluations as early indicators of days open. Dairy form and BCS obtained from the Holstein Association USA, Inc., were merged with mature equivalents (ME) for milk yields and days open data from AIPL-USDA. Cows were required to be classified between 24 and 60 mo of age, before $335 \mathrm{~d}$ in milk (DIM) and have ME milk of at least $4537 \mathrm{~kg}$. A minimum of 20 daughters per sire and 10 cows per herd-classification visit (HV) or herdyear-season of calving (HYS) were required. The final data set included 159,700 records. Heritabilities and correlations among dairy form, BCS, milk yield, and days open were estimated with multiple trait sire models. Fixed effects included age at classification for dairy form and BCS, age at calving for milk yield, HV for dairy form and BCS, HYS for milk yield and days open, DIM within lactation group for dairy form and BCS and lactation group for milk yield and days open. Correlations among dairy form, BCS, and days open were generated with and without a ME milk covariable. Correlations between ME milk and days open were generated with and without covariables for dairy form or BCS. Random effects included sire and error. The genetic correlation estimates of days open with dairy form, $\mathrm{BCS}$, and ME milk were $0.48,-0.30$, and 0.38 , respectively. The genetic correlation estimate between days open and dairy form was 0.38 after adjustment for $\mathrm{ME}$ milk, whereas the genetic correlation between days open and BCS was -0.24 after adjustment for ME milk. Combining dairy form evaluations with days open eval-
\end{abstract}

Received August 24, 2003

Accepted March 27, 2004.

Corresponding author: C. D. Dechow; e-mail: cdd1@psu.edu. uations for 19 recently proven bulls resulted in an average increase of 0.06 for reliability of days open evaluations. The addition of BCS evaluations did not increase reliability when dairy form observations were available.

(Key words: body condition score, dairy form, fertility)

Abbreviation key: $\mathbf{D E}_{\text {both }}=$ daughter equivalents for both days open and indirect traits, $\mathbf{D E}_{\mathbf{D O}}=$ daughter equivalents for days open, $\mathbf{D} \mathbf{E}_{\mathbf{i n d}}=$ daughter equivalents for indirect traits, DPR = daughter pregnancy rate, $\mathbf{H V}=$ herd-classification visit, $\mathbf{H Y S}=$ herd-yearseason, $\mathbf{M E}=$ mature equivalent, $\mathbf{P A}_{\mathbf{D O}}=$ parent average for days open, $\mathbf{P T A} \mathbf{A}_{\mathbf{B C S}}=$ predicted transmitting ability for body condition score, $\mathbf{P T} \mathbf{A}_{\mathbf{D F}}=$ predicted transmitting ability for dairy form, $\mathbf{P T A} \mathbf{A}_{\mathbf{D O}}=$ predicted transmitting ability for days open, $\mathbf{P T A} \mathbf{A}_{\mathbf{D O I}}=$ predicted transmitting ability for days open from indirect traits, $\mathbf{P T A} \mathbf{A}_{\text {ind }}=$ predicted transmitting abilities for indirect traits, $\mathbf{P T A} \mathbf{A}_{\mathbf{M}}=$ predicted transmitting ability for milk yield, $\mathbf{R E L}_{\mathbf{c o m b}}=$ reliability of combined predicted transmitting ability, $\mathbf{R E L}_{\mathbf{d i r}}=$ reliability of a direct prediction, $\mathbf{R E L}_{\mathbf{D O}}=$ reliability of predicted transmitting ability for days open, $\mathbf{R E L}_{\mathbf{i n d}}=$ reliability of an indirect prediction, $\mathbf{R E L}_{\mathbf{P A}}=$ reliability of parent average, $\mathbf{T A}_{\mathbf{D o}}=$ transmitting ability for days open, $\mathbf{T} \mathbf{A}_{\mathbf{i n d}}=$ transmitting abilities for indirect traits.

\section{INTRODUCTION}

Dairy cattle selection programs have emphasized yield traits, whereas lower heritability traits, like fertility, have received little direct selection pressure. However, the genetic variation for fertility measures is substantial, indicating potential to select for improved fertility (Philippson, 1981). Weigel and Rekaya (2000) reported ranges in sire breeding values for $60 \mathrm{~d}$ nonreturn rate of $16 \%$ for several California herds to $30 \%$ in several Minnesota herds. The genetic standard deviation of first-service conception rate was near $0.05 \%$ in 
2 studies (Veerkamp et al., 2001; Berry et al., 2003). The genetic standard deviation of calving interval was reported to be 7 (Pryce et al., 2002) or $9 \mathrm{~d}$ (Veerkamp et al., 2001).

Unfortunately, dairy cattle fertility is unfavorably correlated with yield. Abdallah and McDaniel (2000) estimated that days open increased at a rate of $1.1 \mathrm{~d} /$ yr from 1980 to 1993 as a correlated response to selection for increased yield in 5 North Carolina experimental herds. There also appears to be a trend of less voluntary culling of low-producing cows, which is partly due to reduced fertility, thereby slowing potential genetic improvement (Weigel et al., 2003).

National genetic evaluations for daughter pregnancy rate (DPR) are now available. Daughter pregnancy rates are derived from days open records and have an estimated heritability of 0.04 (VanRaden et al., 2002). Because of the low heritability of DPR, only bulls with many daughters will have high reliability for DPR. Producer confidence may be low for DPR until second-crop daughters are generated. In addition, days open cannot be recorded as early in lactation as production or type traits, resulting in further limits to reliable DPR information for recently proven bulls.

High BCS and low dairy character has been correlated with improved reproductive performance in many studies (Dadati et al., 1986; Pryce et al., 2000; Dechow et al., 2001; Veerkamp et al., 2001; Berry et al., 2003). Cows with high genetic merit for BCS lose less body condition in early lactation, indicating that high genetic merit for BCS is associated with less severe negative energy balance (Dechow et al., 2002). Greater negative energy balance is genetically associated with an increase in days to start of luteal activity after calving (Veerkamp et al., 2000).

Studies in Europe have indicated that selecting for higher BCS will slow the deterioration in fertility as a response to selection for higher yield (Pryce et al., 2002; Berry et al., 2003). The reliability of productive life evaluations in the United States has been improved by using correlated type and production evaluations to predict productive life for recently proven bulls (Weigel et al., 1998, VanRaden, 2001).

The objectives of this study were to estimate correlations among BCS, dairy form, yield, and days open in the United States and to investigate the potential use of BCS, dairy form, or yield evaluations to increase the reliability of genetic evaluations for days open.

\section{MATERIALS AND METHODS}

\section{Data}

Classification data, including BCS and dairy form recorded during linear type evaluation from October
1997 through June 2000, were obtained from the Holstein Association USA. Heritability and correlation estimates among BCS, dairy form, and other linear type traits using these data were previously reported by Dechow et al. (2003). A total of 728,597 classification records from 613,338 cows were included in the initial data set. Body condition score was recorded on a scale of 1 (thin) to 50 (fat). Body condition score and dairy form records from classifiers that had assigned an unusually high frequency of cows a single BCS were removed, as in Dechow et al. (2003). Records from cows that were classified between 24 and 60 mo of age were retained, and records containing classifications after 335 DIM were eliminated. Only the first available classification record for each cow was retained to eliminate the need for a permanent environmental effect. A total of 332,517 classification records remained after the above edits.

Production data, including mature equivalent (ME) 305-d milk yield and days open from 1997 through December 2002, were provided by the Animal Improvement Programs Laboratory at USDA (AIPL-USDA). Days open are converted to DPR in national genetic evaluations in the United States (VanRaden et al., 2002) but were left as days open for this study. The original data set included 14,813,461 records from $7,149,074$ cows. Cows were required to have ME milk of at least $4537 \mathrm{~kg}$. Days open less than $25 \mathrm{~d}$ were eliminated. Days open greater than $250 \mathrm{~d}$ were set to 250 , as in the national genetic evaluations for days open (VanRaden et al., 2002).

The classification data set and production data set were merged. Only cows with records in both data sets and only one record per cow were retained for computational feasibility. Contemporary group effects were herd-classification visit (HV) for the classification data and herd-year-season of calving (HYS) for production data. Herd year of calving was substituted for HYS groups with fewer than 10 cows. Three seasons were defined: January through April, May through August, and September through December. A minimum of 10 cows per HYS or HV and 20 daughters per sire were required. The final data set included 114,612 first-lactation, 33,765 second-lactation, 11,215 third-lactation, and 108 fourth-lactation records, for a total of 159,700 records. The cows were sired by 1165 bulls, and relationships among all bulls were obtained by tracing 4 generations of sires and dams for each bull, resulting in a pedigree file that included 2292 individuals.

\section{Statistical Analyses}

All traits were analyzed with multiple-trait sire models in ASREML (Gilmour et al., 2002). The basic statistical model used in the analyses was: 


$$
\begin{gathered}
\mathbf{y}=\mathbf{b}_{1} * \operatorname{age}(\mathbf{L G}) \\
+\sum_{\mathrm{m}=2}^{6} \mathbf{b}_{x} * \mathbf{D I M}^{\mathrm{m}-1}(\mathbf{L G}) \\
+\mathbf{C G}+\operatorname{Sire}+\varepsilon
\end{gathered}
$$

where

$$
\begin{aligned}
\mathbf{y}= & \text { a vector of length } 2 \text { to } 3, \text { including BCS, } \\
& \text { dairy form, days open or ME milk; } \\
\mathbf{b}_{1}= & \text { a vector of regression coefficients on age } \\
& \text { in months, nested within lactation group; } \\
\mathbf{b}_{\mathbf{x}}= & \text { a vector of regression coefficients of order } \\
& 1 \text { through } 5 \text { on DIM within lactation group } \\
& \text { and were included for BCS and dairy form } \\
& \text { only; } \\
\mathbf{C G}= & \text { a vector of fixed effects for contemporary } \\
& \text { group; } \\
\mathbf{S i r e}= & \text { a vector of random effects for sire; and } \\
\varepsilon= & \text { a vector of random errors. }
\end{aligned}
$$

Three lactation groups were defined as first lactation, second lactation, and third plus fourth lactations. Age was age at calving for ME milk and age at classification for BCS and dairy form. Age was not included in analysis of days open. Poor fertility is likely to increase age at calving, and adjusting for age would then eliminate variance in days open that may be due to genetic differences for fertility (VanRaden et al., 2002). Contemporary group effects were HV $(n=10,807)$ for $\mathrm{BCS}$ and dairy form, and HYS ( $\mathrm{n}=15,916)$ for ME milk and days open. Lactation group was included as a fixed effect for ME milk and days open. Analyses among BCS, dairy form, and days open were conducted with and without ME milk as a covariable. Likewise, analyses among BCS, dairy form, ME milk, and days open were conducted with and without a covariable for BCS or dairy form.

\section{Indirect Prediction of Days Open}

The potential of using BCS, dairy form, or milk yield evaluations as indicators of PTA for days open $\left(\mathbf{P T A}_{\mathrm{DO}}\right)$ was investigated by comparing the reliability of $\mathrm{PTA}_{\mathrm{DO}}$ $\left(\mathbf{R E L}_{\mathrm{DO}}\right)$ under the following scenarios: 1) PTA $\mathrm{DO}_{\mathrm{DO}}$ was generated directly with daughter observations for days open; 2) PTA $_{\text {DO }}$ was generated indirectly $\left(\mathbf{P T A}_{\mathrm{DOI}}\right)$ with PTA or combinations of PTA for BCS (PTA $\mathbf{B C S}_{\mathrm{BCS}}$ ), dairy form $\left(\mathbf{P T A}_{\mathrm{DF}}\right)$, and $\mathrm{ME}$ milk $\left(\mathbf{P T A} \mathbf{A}_{\mathrm{M}}\right)$; and 3) $\mathrm{PTA}_{\mathrm{DO}}$ from scenario 1 combined with $\mathrm{PTA}_{\mathrm{DOI}}$ from scenario 2. Direct REL $\left(\mathbf{R E L}_{\mathrm{dir}}\right)$ for $\mathrm{PTA}_{\mathrm{DO}}, \mathrm{PTA}_{\mathrm{BCS}}, \mathrm{PTA}_{\mathrm{M}}$, and PTA $_{\text {DF }}$ was calculated as (Van Vleck, 1993):

$$
\mathrm{REL}_{\text {dir }}=\mathrm{n} \div(\mathrm{n}+\mathrm{k})
$$

where $\mathrm{n}=$ the number of daughters

$$
\text { and } \mathrm{k}=\left(4-\mathrm{h}_{2}\right) \div \mathrm{h}_{2} \text {. }
$$

The REL of PTA $\mathrm{DOI}_{\text {was }}$ calculated with formulas used to calculate REL for indirect predictions of productive life with production and type data (Weigel et al., 1998). Reliability for an indirect prediction $\left(\mathbf{R E L}_{\mathbf{i n d}}\right)$ was calculated as:

$$
\begin{gathered}
\mathrm{REL}_{\text {ind }}=\operatorname{Cov}\left(\mathrm{TA}_{\mathrm{DO}}, \mathrm{TA}_{\text {ind }}\right)^{\prime} \\
\left(\operatorname{Var}\left[\mathrm{TA}_{\text {ind }}\right]\right)^{-1}\left(\operatorname{Var}\left[\mathrm{PTA}_{\text {ind }}\right]\right) \\
\left(\operatorname{Var}\left[\mathrm{TA}_{\text {ind }}\right]\right)^{-1} \operatorname{Cov}\left[\mathrm{TA}_{\mathrm{DO}}, \mathrm{TA}_{\text {ind }}\right] / \operatorname{Var}\left(\mathrm{TA}_{\mathrm{DO}}\right),
\end{gathered}
$$

where $\mathrm{TA}_{\mathrm{DO}}=$ transmitting ability for days open $\left(\mathbf{T A} \mathbf{D O}_{\mathrm{DO}}\right), \mathrm{TA}_{\text {ind }}=$ a vector of transmitting abilities for the indicators of days open ( $\mathbf{T} \mathbf{A}_{\text {ind }}$ ) (BCS, dairy form, and $\mathrm{ME}$ milk), and $\mathrm{PTA}_{\text {ind }}=$ a vector of $\mathrm{BLUP}$ predictions of TA $A_{\text {ind }}\left(\mathbf{P T A}_{\text {ind }}\right)$. The variance of $\mathrm{PTA}_{\mathrm{BCS}}, \mathrm{PTA}_{\mathrm{DF}}$, and $\mathrm{PTA}_{\mathrm{M}}$ was calculated by multiplying TA variance times REL for BCS, dairy form, or ME milk.

The combined REL ( $\left.\mathbf{R E L}_{\text {comb }}\right)$ can then be calculated as follows (Weigel et al., 1998):

$$
\begin{gathered}
\mathrm{REL}_{\text {comb }}= \\
\frac{\mathrm{REL}_{\text {dir }}+\mathrm{REL}_{\text {ind }}-2 \mathrm{REL}_{\text {dir }} \mathrm{REL}_{\text {ind }} * \mathrm{c}}{1-\mathrm{REL}_{\mathrm{dir}} \mathrm{REL}_{\text {ind }} * \mathrm{c}^{2}}
\end{gathered}
$$

where $\mathrm{c}=1+\left(\mathrm{DE}_{\mathrm{both}} / \mathrm{DE}_{\mathrm{DO}} \mathrm{DE}_{\text {ind }}\right) \times\left(\left[4-\mathrm{h}_{\mathrm{DO}}^{2}\right][4-\right.$ $\left.\left.\mathrm{h}^{2}{ }_{\text {ind }}\right] \div\left[\mathrm{h}^{2}{ }_{\mathrm{DO}} \mathrm{h}^{2}{ }_{\text {ind }}\right]\right)^{0.5}$. Cows with records for days open contribute daughter equivalents for days open $\left(\mathbf{D E}_{\mathrm{DO}}\right)$, cows with classification records contribute indirect daughter equivalents $\left(\mathbf{D E}_{\text {ind }}\right)$, and cows with classification records and days open contribute to daughter equivalents both $\left(\mathbf{D E}_{\text {both }}\right)$. When no daughters have both classification records and days open observations, $\mathrm{DE}_{\mathrm{both}}=0$ and $\mathrm{c}=1$.

The REL $\mathrm{DO}_{\mathrm{D}}$ when $\mathrm{PTA}_{\mathrm{DO}}$ and $\mathrm{PTA}_{\mathrm{DOI}}$ are combined with parent average for days open (PA $\mathbf{P A O}_{\mathbf{D O}}$ ) was calculated using equation [2]. Reliability for PA $\left(\mathbf{R E L} \mathbf{L}_{\mathrm{PA}}\right)$ is substituted for $\mathrm{REL}_{\text {ind }}$, and $\mathrm{REL}_{\text {comb }}$ is substituted for $\mathrm{REL}_{\mathrm{dir}}$. If it is assumed that a young bull has no daughters for days open and, therefore, does not contribute to his $\mathrm{PA}_{\mathrm{DO}}$, then $\mathrm{DE}_{\text {both }}$ becomes zero and $\mathrm{c}=1$ and can be dropped from equation [2]. This gives the same formula used by Harris and Johnson (1998) to approximate REL from 2 separate sources of information and is an accurate and unbiased approximation of true reliability.

The expected $R E L_{\mathrm{PA}}$ of a young bull was estimated by averaging REL $L_{\mathrm{PA}}$ for 473 young bulls born after 1997 
Table 1. Heritabilities (diagonal), genetic (above diagonal), and phenotypic (below diagonal) correlations among BCS, dairy form, mature equivalent (ME) milk, and days open. ${ }^{1}$

\begin{tabular}{lrrrr}
\hline & BCS & Dairy form & ME Milk & Days open \\
\hline BCS & 0.22 & -0.73 & -0.25 & -0.30 \\
Dairy form & -0.45 & 0.25 & 0.49 & 0.48 \\
ME milk & -0.17 & 0.42 & 0.25 & 0.38 \\
Days open & -0.07 & 0.09 & 0.15 & 0.04 \\
\hline
\end{tabular}

${ }^{1}$ Standard errors range from 0.005 to 0.014 for heritability estimates, are 0.003 for phenotypic correlation estimates, and range from 0.02 to 0.06 for genetic correlation estimates.

with daughters that had milk yield records, but no daughters for days open in national genetic evaluations for May 2003 (AIPL-USDA, Beltsville, MD). The RELPA of this population of bulls should approximate the expected $\mathrm{REL}_{\mathrm{PA}}$ for bulls that are about to receive their first official proof and enter active service.

Indirect predictions for PTA $\mathrm{DO}_{\mathrm{DO}}$ would be of most value for recently proven bulls that have few daughters with days open observations. Therefore, the number of daughters for days open, dairy form, and milk yield and REL for PTA $A_{D O}$, PTA bulls born in 1997 or later that had entered active service between June 1999 and November 1999 and were on the High Ranking Sire Report for Type-Production Index from the Holstein Association USA, Inc., in May 2003. This group of bulls should represent newly proven bulls that are likely to be widely used by US dairy producers. Nineteen bulls met all the criteria listed above.

\section{RESULTS AND DISCUSSION}

\section{Heritabilities and Correlations}

Heritabilities and correlations among BCS, dairy form, days open, and ME milk are shown in Table 1. The heritability and correlation estimates among dairy form and BCS were nearly identical to those reported by Dechow et al. (2003) using a similar subset of these data.

The heritability estimates of ME milk and days open were 0.25 and 0.04 , respectively, which compares to heritability estimates of 0.30 for milk yield and 0.04 for DPR currently used in national genetic evaluations with an animal model (VanRaden and Seykora, 2003). The genetic correlation estimate between ME milk and days open was estimated to be 0.38 , which compares to the genetic correlation of -0.35 assumed between $\mathrm{PTA}_{\mathrm{M}}$ and DPR in national genetic evaluations (VanRaden and Seykora, 2003).

The genetic correlation estimates of ME milk with BCS and dairy form were -0.25 and 0.49 , respectively.
The phenotypic correlation estimate between ME milk and BCS was -0.17 , whereas the phenotypic correlation estimate between ME milk and dairy form was 0.42 . These correlation estimates are similar to previously reported estimates of genetic correlations among $\mathrm{ME}$ milk, BCS, and dairy form. Short and Lawlor (1992) reported a genetic correlation estimate of 0.54 between lactation yield and dairy form. Estimates of the genetic correlation between BCS and milk yield range from -0.51 to -0.28 (Dechow et al., 2001; Veerkamp et al., 2001; Berry et al., 2003). Clearly, cows with high genetic merit for yield have lower BCS and higher dairy form, but the correlation is low to moderate.

The genetic and phenotypic correlation estimates between days open and BCS are -0.30 and -0.07 , respectively. The genetic (0.48) and phenotypic (0.09) correlation estimates between dairy form and days open were stronger than between BCS and days open. Pryce et al. (2000) also reported a slightly stronger correlation (0.47) between angularity in the United Kingdom (similar to US dairy form) and calving interval than for BCS and calving interval $(-0.40)$.

Dairy form was more highly correlated with fertility than BCS in this study. The physiological relationship among dairy form, fertility, and energy balance has not been as well studied as the relationship among BCS, fertility, and energy balance. Body condition scores are generally assigned based on a visual assessment of the pelvic region only, whereas dairy form is ideally assigned on a visual assessment of the rib structure. However, it is likely that many classifiers analyze the overall tendency of a cow to be angular and thin instead of simply assigning dairy form scores based on an assessment of the rib structure. Dairy form, as it is currently evaluated, may be more highly correlated with differences in total internal and external body fat than BCS, particularly through the front end and over the rib structure.

Genetic tendency toward lower BCS or higher dairy form is correlated with extended days open across a range of studies. The genetic correlation between BCS and days to last service confirmed by a subsequent calving (which could also be considered days open) was reported to be -0.41 (Veerkamp et al., 2001). Genetic correlation estimates among calving interval and dairyness (0.43) and dairy character (0.38) were unfavorable in Canadian Holsteins classified between 1976 and 1983 (Dadati et al., 1986).

Cows genetically inclined to be thin appear to be most susceptible to an extended interval between calving and when luteal activity resumes, estrus is displayed, or insemination occurs. Royal et al. (2002) inferred a genetic correlation estimate between BCS and the interval from calving to commencement of luteal activity, as 
determined by milk progesterone testing of -0.84 in the United Kingdom. This is likely due to energy balance differences among cows that are reflected in differences of BCS. The genetic correlation between energy balance and commencement of luteal activity was estimated to be 0.60 in a research herd in The Netherlands (Veerkamp et al., 2000). Butler et al. (1981) reported that ovulation occurred at an average of $10 \mathrm{~d}$ after maximal daily negative energy balance, whereas de Vries et al. (1999) reported that total negative energy balance and maximal negative energy balance were both correlated with an increase in interval to first observed estrus.

Harrison et al. (1990) reported greater early lactation negative energy balance in cows selected for high genetic merit for yield vs. cows selected for average genetic merit. The cows selected for high genetic merit for yield did not have a significant delay in days to first ovulation but did have a significant delay in days to first visual estrus (66 vs. $43 \mathrm{~d}$ ). The genetic correlation between days to first heat and BCS $10 \mathrm{wk}$ in lactation was reported to be -0.49 (Pryce et al., 2001). Genetic correlation estimates between days to first service and BCS during the lactation range from -0.76 to -0.37 over a range of studies from different countries (Pryce et al., 2000; Dechow et al., 2001; Veerkamp et al., 2001; Berry et al., 2003).

In many studies, higher BCS also tends to be correlated with increased likelihood of conception. The genetic correlation estimates between BCS during the lactation and services per conception range from -0.42 to -0.03 (Dechow et al., 2001; Veerkamp et al., 2001; Berry et al., 2003). Genetic correlation estimates between BCS and first-service conception were 0.34 (Berry et al., 2003) and 0.20 (Veerkamp et al., 2001).

The genetic relationship between BCS or dairy form and days open is dependent on the genetic relationship of BCS or dairy form with both days to first service and likelihood of successful conception. Genetic correlation estimates are stronger between BCS and days to first service than genetic correlation estimates between BCS and conception-related traits. Genetic correlation estimates with days open tend to be intermediate to correlation estimates with days to first service and conceptionrelated traits. Delays in commencement of luteal activity or estrus in cows that are experiencing greater negative energy balance are likely the most important underlying physiological factors for the genetic relationship of BCS and dairy form with days open.

\section{Adjustment for ME Milk}

Genetic and phenotypic correlations among BCS, dairy form, and days open after adjustment for ME milk
Table 2. Genetic (above diagonal) and phenotypic (below diagonal) correlations among BCS, dairy form, and days open adjusted for mature equivalent milk. ${ }^{1}$

\begin{tabular}{lccc}
\hline & BCS & Dairy form & Days open \\
\hline BCS & & -0.71 & -0.24 \\
$\begin{array}{l}\text { Dairy form } \\
\text { Days open }\end{array}$ & -0.43 & & 0.38 \\
\hline
\end{tabular}

${ }^{1}$ Standard errors are 0.003 for phenotypic correlation estimates and range from 0.02 to 0.06 for genetic correlation estimates.

yield are reported in Table 2. The genetic correlation estimates of days open with BCS and dairy form were -0.24 and 0.38 after adjustment for ME milk, respectively. Pryce et al. (2002) estimated the genetic correlation between BCS and calving interval to be -0.48 before and -0.22 after adjustment for milk yield. Dechow et al. (2001) reported genetic correlation estimates between BCS during the lactation and days to first service ranging from -0.76 to -0.42 before and from -0.72 to -0.40 after adjustment for ME milk, respectively. The genetic correlation between energy balance and the start of luteal activity was -0.60 before adjustment for yield and -0.49 after adjustment for yield (Veerkamp et al., 2000). The genetic relationship between days open and BCS, dairy form, or energy balance is not the only result of production differences among cows. Cows with higher BCS or lower dairy form at a given level of yield should have fewer days open, and selection to limit change in BCS or dairy form may help reduce the unfavorable correlated response in days open when selecting for yield (Pryce et al., 2002).

\section{Adjustment for BCS and Dairy Form}

Genetic correlation estimates of days open with dairy form, BCS, or ME milk after adjustment for BCS or dairy form are given in Table 3 . The genetic correlation between BCS and days open was zero after adjusting

Table 3. Genetic $\left(r_{g}\right)$ and phenotypic $\left(r_{p}\right)$ correlations of BCS with days open adjusted for dairy form, of dairy form with days open adjusted for BCS, and of mature equivalent (ME) milk with days open adjusted for BCS or dairy form. ${ }^{1}$

\begin{tabular}{|c|c|c|}
\hline & \multicolumn{2}{|c|}{ Correlations with days open } \\
\hline & $r_{g}$ & $r_{p}$ \\
\hline $\mathrm{BCS}^{2}$ & 0.0 & -0.04 \\
\hline Dairy form ${ }^{3}$ & 0.40 & 0.06 \\
\hline ME milk ${ }^{2}$ & 0.22 & 0.13 \\
\hline ME milk ${ }^{3}$ & 0.33 & 0.14 \\
\hline
\end{tabular}

${ }^{1}$ Standard errors are 0.003 for phenotypic correlation estimates and range from 0.06 to 0.07 for genetic correlation estimates.

${ }^{2}$ Dairy form was included in the model as a covariate.

${ }^{3} \mathrm{BCS}$ was included in the model as a covariate. 


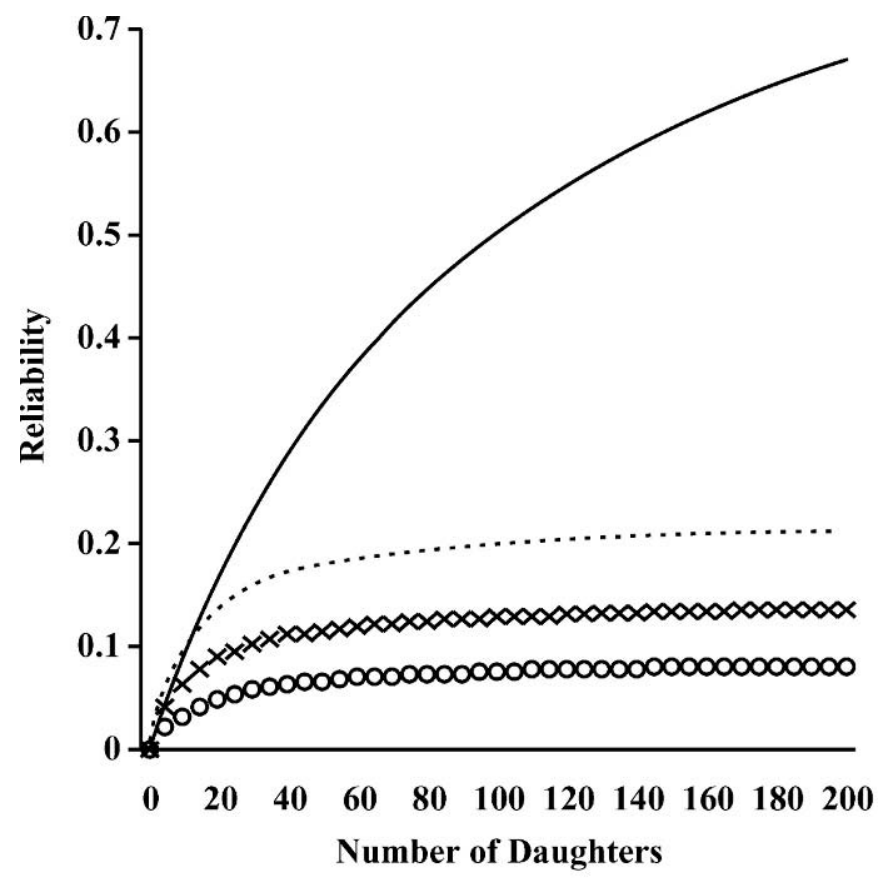

— Days Open $\quad$ O BCS $\times$ ME Milk … Dairy Form

Figure 1. Reliability of predicted transmitting ability (PTA) for days open, with direct days open observations and indirect prediction of PTA for days open with BCS, dairy form, and mature equivalent (ME) milk.

for dairy form, but the genetic correlation between dairy form and days open was 0.40 after adjustment for BCS.

The genetic correlation estimate between ME milk and days open was 0.33 after adjustment for BCS and 0.22 after adjustment for dairy form. An unfavorable genetic relationship between ME milk and days open exists even after one adjusts for dairy form. The squared genetic correlation between ME milk and days open when not adjusted for dairy form indicates that genetic differences among cows in ME milk explain approximately $14.4 \%$ of the genetic difference among cows in days open. The squared genetic correlation between $\mathrm{ME}$ milk and days open is only $4.8 \%$ after adjustment for dairy form. This indicates that a majority of the unfavorable relationship between ME milk and days open is likely due to higher dairy form for cows with high genetic merit for yield.

\section{Indirect Prediction of Days Open}

The REL $L_{D O}$ when genetic evaluations for days open were predicted with $\mathrm{PTA}_{\mathrm{DO}}, \mathrm{PTA}_{\mathrm{DF}}$, $\mathrm{PTA}_{\mathrm{BCS}}$, or $\mathrm{PTA}_{\mathrm{M}}$ are shown in Figure 1. The REL $\mathrm{DO}_{\mathrm{DO}}$ for a sire with observations from 200 daughters was 0.08 when $\mathrm{PTA}_{\mathrm{DOI}}$ was derived from $\mathrm{PTA}_{\mathrm{BCS}}, 0.14$ when derived from $\mathrm{PTA}_{\mathrm{M}}$,

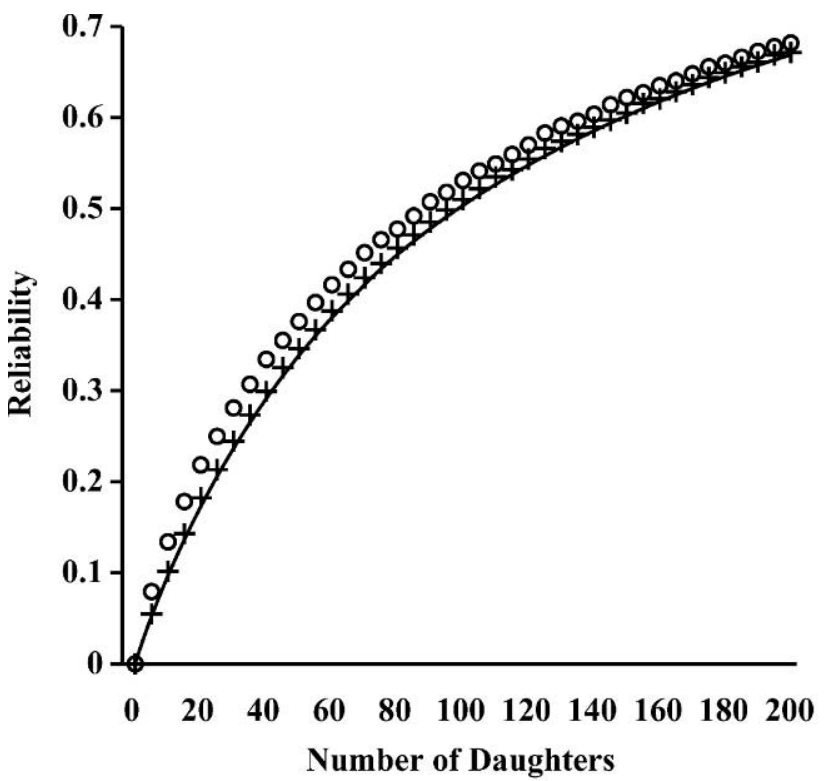

— Days Open O Days Open + Dairy Form +Days Open + BCS

Figure 2. Reliability of predicted transmitting ability for days open, with direct days open observations combined with dairy form, or body condition score (BCS) observations. An equal number of daughters for days open and classification data is assumed, and all daughters with a days open observation also have observations for BCS and dairy form.

and 0.21 when derived from PTA $\mathrm{DF}_{\mathrm{DF}}$. With 200 daughters that have direct days open observations, REL $\mathrm{DO}_{\mathrm{D}}$ was 0.67 . With 10 daughters or fewer, $\mathrm{PTA}_{\mathrm{DF}}$ was a more reliable predictor of $\mathrm{PTA}_{\mathrm{DO}}$ than the direct estimate of PTA $\mathrm{DO}$.

With 200 daughters, REL $\mathrm{DO}_{\mathrm{DO}}$ when PTA $\mathrm{DOI}_{\mathrm{D}}$ was derived from $\mathrm{PTA}_{\mathrm{BCS}}+\mathrm{PTA}_{\mathrm{DF}}$ or $\mathrm{PTA}_{\mathrm{BCS}}+\mathrm{PTA}_{\mathrm{M}}$ was 0.22 and 0.18 , respectively (not shown). Reliability of days open predicted with $\mathrm{PTA}_{\mathrm{DF}}+\mathrm{PTA}_{\mathrm{M}}$ was 0.24 , and $R E L_{D O}$ when predicted with $\mathrm{PTA}_{\mathrm{BCS}}+\mathrm{PTA}_{\mathrm{DF}}+\mathrm{PTA}_{\mathrm{M}}$ was 0.25 with 200 daughters.

Reliability of days open when $\mathrm{PTA}_{\mathrm{DO}}$ is combined

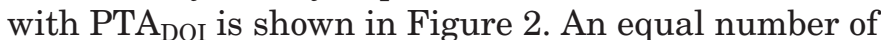
daughters with days open, ME milk, BCS, and dairy form records are assumed, and all daughters with days open are assumed to have ME milk, BCS, and dairy form records. The maximum gain in $\mathrm{REL}_{\mathrm{DO}}$ was 0.012 when $\mathrm{PTA}_{\mathrm{DO}}$ is combined with $\mathrm{PTA}_{\mathrm{BCS}}, 0.048$ when $\mathrm{PTA}_{\mathrm{DO}}$ is combined with $\mathrm{PTA}_{\mathrm{DF}}$, and 0.029 when $\mathrm{PTA}_{\mathrm{DO}}$ is combined with $\mathrm{PTA}_{\mathrm{M}}$ (not shown).

The effect of combining PTA $_{\mathrm{DO}}$ and $\mathrm{PTA}_{\mathrm{DOI}}$ when $\mathrm{PA}_{\mathrm{DO}}$ is available is shown in Figure 3. The average REL for $\mathrm{PA}_{\mathrm{DO}}$ of 473 young sires that should soon have production and type proofs was 0.36 . Therefore, a REL $_{\mathrm{PA}}$ of 0.36 was assumed for $\mathrm{PTA}_{\mathrm{DO}}, \mathrm{PTA}_{\mathrm{DF}}, \mathrm{PTA}_{\mathrm{BCS}}$, and $\mathrm{PTA}_{\mathrm{M}}$. The maximum gain in $\mathrm{REL}_{\mathrm{DO}}$ was 0.023 


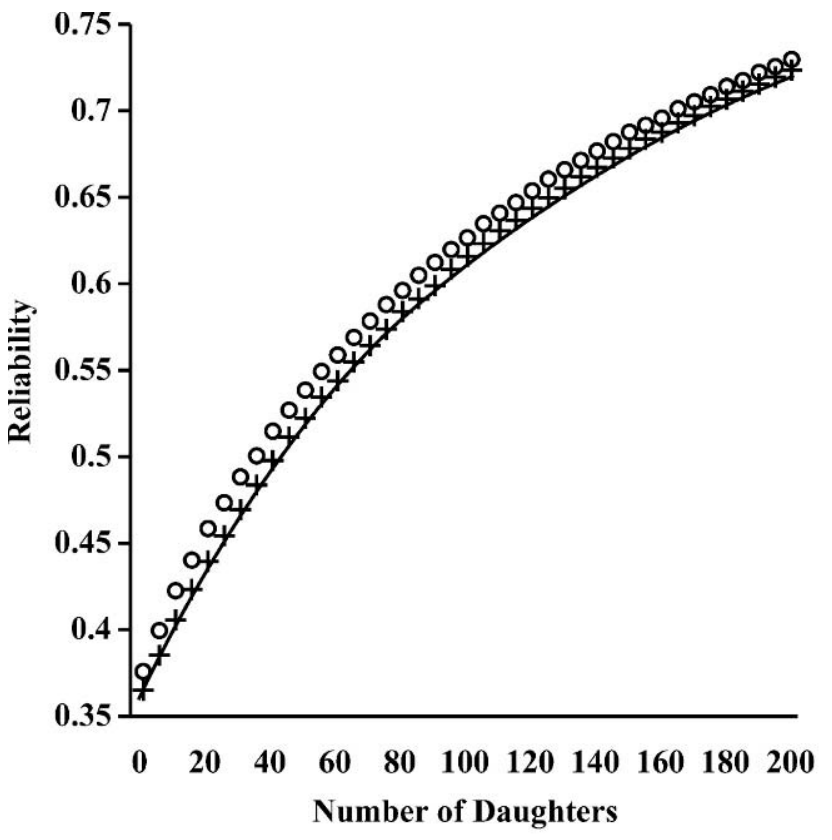

— Days Open O Days Open + Dairy Form +Days Open + BCS

Figure 3. Reliability of PTA for days open, with direct days open observations combined with dairy form or BCS, and parent average for days open. An equal number of daughters for days open, BCS, and dairy form are assumed, and all daughters with a days open observation also have observations for BCS and dairy form.

when $\mathrm{PTA}_{\mathrm{DO}}$ is combined with $\mathrm{PTA}_{\mathrm{DF}}, 0.006$ when combined with $\mathrm{PTA}_{\mathrm{BCS}}, 0.014$ when combined with $\mathrm{PTA}_{\mathrm{M}}$ (not shown), and 0.029 when combined with $\mathrm{PTA}_{\mathrm{DF}}+$ $\mathrm{PTA}_{\mathrm{BCS}}+\mathrm{PTA}_{\mathrm{M}}$ (not shown).

Figures 2 and 3 assume an equal number of daughters for ME milk, days open, BCS, and dairy form, which is not realistic. The minimum, maximum, and average number of daughters per sire for dairy form, $\mathrm{PTA}_{\mathrm{DO}}$ (which is DPR in US genetic evaluations), and $\mathrm{PTA}_{\mathrm{M}}$ for 19 recently proven bulls are given in Table 4 . The average number of daughters for $\mathrm{PTA}_{\mathrm{DO}}$ was 27 , the average number of daughters for $\mathrm{PTA}_{\mathrm{DF}}$ was 55 , and the average number of daughters for $\mathrm{PTA}_{\mathrm{M}}$ was 100 . Daughter observations for days open are not available until near the end of a cow's lactation, or the beginning of a subsequent lactation if derived from calving intervals. Dairy form and ME milk can be recorded earlier in lactation than days open, and newly proven bulls have more daughters with dairy form and ME milk than with days open.

The minimum, maximum, and average REL for $\mathrm{PTA}_{\mathrm{DO}}, \mathrm{PTA}_{\mathrm{DF}}$, and $\mathrm{PTA}_{\mathrm{M}}$, plus the expected change in REL $_{\mathrm{DO}}$ when PTA $\mathrm{DO}_{\mathrm{DO}}$ is combined with PTA $\mathrm{DF}_{\mathrm{DF}}, \mathrm{PTA}_{\mathrm{BCS}}$, $\mathrm{PTA}_{\mathrm{M}}$, or $\mathrm{PTA}_{\mathrm{DF}}+\mathrm{PTA}_{\mathrm{BCS}}+\mathrm{PTA}_{\mathrm{M}}$, are also reported in Table 4. The number of daughters with BCS observations and average reliability for BCS is assumed to be
Table 4. Minimum (Min), maximum (Max), and average (Ave) number of daughters (n) for dairy form, daughter pregnancy rate (DPR), and predicted transmitting ability for milk yield (PTAM) and official reliability for dairy form, DPR, and PTAM for 19 recently proven high ranking Holstein sires and increase in reliability for DPR when dairy form (+DF), BCS (+BCS), PTAM (+PTAM), or dairy form, BCS, and PTAM (+DF+PTAM+BCS) are combined with DPR.

\begin{tabular}{lccc}
\hline & Min & Max & Ave \\
\hline DPR (n) & 4 & 99 & 27 \\
Dairy form (n) & 29 & 114 & 55 \\
PTAM (n) & 55 & 173 & 100 \\
Reliability & & & \\
Dairy form & 0.75 & 0.90 & 0.81 \\
PTAM & 0.80 & 0.92 & 0.86 \\
DPR & 0.37 & 0.62 & 0.44 \\
Reliability increase & & & \\
+DF & 0.03 & 0.08 & 0.06 \\
+BCS & 0.01 & 0.03 & 0.02 \\
+PTAM & 0.02 & 0.05 & 0.04 \\
+DF + PTAM + BCS & 0.04 & 0.09 & 0.07 \\
\hline
\end{tabular}

the same as for dairy form. The average RELDO was 0.44. The average change in $\mathrm{REL}_{\mathrm{DO}}$ if $\mathrm{PTA}_{\mathrm{DF}}, \mathrm{PTA}_{\mathrm{BCS}}$, $\mathrm{PTA}_{\mathrm{M}}$, or $\mathrm{PTA}_{\mathrm{DF}}+\mathrm{PTA}_{\mathrm{BCS}}+\mathrm{PTA}_{\mathrm{M}}$ are combined with $\mathrm{PTA}_{\mathrm{DO}}$ is $0.06,0.02,0.04$, and 0.07 , respectively. The maximum expected change in $\mathrm{REL}_{\mathrm{DO}}$ was 0.08 if $\mathrm{PTA}_{\mathrm{DF}}$ is combined with $\mathrm{PTA}_{\mathrm{DO}}$ and 0.09 if $\mathrm{PTA}_{\mathrm{DF}}+\mathrm{PTA}_{\mathrm{BCS}}$ $+\mathrm{PTA}_{\mathrm{M}}$ is combined with $\mathrm{PTA}_{\mathrm{DO}}$ for a bull with 4 daughters with days open, 52 daughters with dairy form, and 75 daughters with $\mathrm{ME}$ milk records.

\section{CONCLUSIONS}

Genetic evaluations for dairy form, BCS, or ME milk could be used to increase the accuracy of $\mathrm{PTA}_{\mathrm{DO}}$ for bulls that have few daughters with direct days open observations. Dairy form was the most accurate days open predictor of the traits studied here. The maximum increase in $\mathrm{REL}_{\mathrm{DO}}$ for 19 recently proven bulls was 0.08 when direct $\mathrm{PTA}_{\mathrm{DO}}$ is combined with $\mathrm{PTA}_{\mathrm{DF}}$.

Dairy form is positively weighted when assigning final type score during linear classification, despite an unfavorable relationship with fertility. A favorable correlation of dairy form with economically important yield traits justifies some positive weight on dairy form when assigning phenotypic final type scores. However, positive weight on dairy form in genetic selection programs is unnecessary because direct and accurate genetic evaluations for yield are available. Dairy form should thus receive negative weight in breeding goals to help limit the unfavorable response in days open to selection for higher yield. Fertility has a higher economic importance than final type score for commercial producers, so most producers will be receptive to selecting for lower dairy form.

There was little gain in $\mathrm{REL}_{\mathrm{DO}}$ by including $\mathrm{BCS}$ evaluations when dairy form evaluations were avail- 
able. There may be advantages to selecting for BCS, however. More producers routinely use and are familiar with BCS than with dairy form scores. Evaluation procedures for scoring body condition are well documented and may be less likely to change than procedures for scoring dairy form. Additionally, selection for higher BCS may be more acceptable than selecting against dairy form for some producers.

\section{ACKNOWLEDGMENTS}

Appreciation is expressed to the Holstein Association USA and to the National Milk Producers Federation for providing financial assistance. The authors thank the Holstein Association USA and AIPL-USDA for providing data.

\section{REFERENCES}

Abdallah, J. M., and B. T. McDaniel. 2000. Genetic parameters and trends of milk, fat, days open, and body weight after calving in North Carolina experimental herds. J. Dairy Sci. 83:1364-1370.

Berry, D. P., F. Buckley, P. Dillon, R. D. Evans, M. Rath, and R. F. Veerkamp. 2003. Genetic relationships among body condition score, body weight, milk yield, and fertility in dairy cows. J. Dairy Sci. 86:2193-2204.

Butler, W. R., R. W. Everett, and C. E. Coppock. 1981. The relationships between energy balance, milk production and ovulation in postpartum Holstein cows. J. Anim. Sci. 53:742-748.

Dadati, E., B. W. Kennedy, and E. B. Burnside. 1986. Relationships between conformation and calving interval in Holstein cows. J. Dairy Sci. 69:3112-3119.

de Vries, M. J., S. Van Der Beek, L. M. T. E. Kaal-Lansbergen, W. Ouweltjes, and J. B. M. Wilmink. 1999. Modeling of energy balance in early lactation and the effect of energy deficits in early lactation on first detected estrus postpartum in dairy cows. J. Dairy Sci. 82:1927-1934.

Dechow, C. D., G. W. Rogers, and J. S. Clay. 2001. Heritabilities and correlations among body condition scores, production traits, and reproductive performance. J. Dairy Sci. 84:266-275.

Dechow, C. D., G. W. Rogers, and J. S. Clay. 2002. Heritability and correlations among body condition score loss, body condition score, production and reproductive performance. J. Dairy Sci. 85:3062-3070.

Dechow, C. D., G. W. Rogers, L. Klei, and T. J. Lawlor. 2003. Heritabilities and correlations among body condition score, dairy form and selected linear type traits. J. Dairy Sci. 86:2236-2242.

Gilmour, A. R., B. R. Cullis, S. J. Welham, and R. Thompson. 2002. ASREML Reference Manual. ftp:ftp.res.bbsrc.ac.uk/pub/aar.

Harris, B., and D. Johnson. 1998. Approximate reliability of genetic evaluations under an animal model. J. Dairy Sci. 81:2723-2728.
Harrison, R. O., S. P. Ford, J. W. Young, A. J. Conley, and A. E. Freeman. 1990. Increased milk production versus reproductive and energy status of high producing dairy cows. J. Dairy Sci. 73:2749-2758.

Philipsson, J. 1981. Genetic aspects of female fertility in dairy cattle. Livest. Prod. Sci. 8:307-319.

Pryce, J. E., M. P. Coffey, and S. Brotherstone. 2000. The genetic relationship between calving interval, body condition score and linear type and management traits in registered Holsteins. J. Dairy Sci. 83:2664-2671.

Pryce, J. E., M. P. Coffey, S. H. Brotherstone, and J. A. Woolliams. 2002. Genetic relationships between calving interval and body condition score conditional on milk yield. J. Dairy Sci. 85:1590-1595.

Pryce, J. E., M. P. Coffey, and G. Simm. 2001. The relationship between body condition score and reproductive performance. J. Dairy Sci. 84:1508-1515.

Royal, M. D., J. E. Pryce, J. A. Woolliams, and A. P. F. Flint. 2002. The genetic relationship between commencement of luteal activity and calving interval, body condition score, production, and linear type traits in Holstein-Friesian dairy cattle. J. Dairy Sci. 85:3071-3080.

Short, T. H., and T. J. Lawlor. 1992. Genetic parameters of conformation traits, milk yield, and herd life in Holsteins. J. Dairy Sci. 75:1987-1998.

VanRaden, P. M. 2001. Methods to combine estimated breeding values obtained from separate sources. J. Dairy Sci. 84(Suppl. E):E47-E55.

VanRaden, P. M., A. Sanders, M. Tooker, B. Miller, and D. Norman. 2002. Daughter pregnancy rate evaluation of cow fertility. AIPL Research Report: DPR1 (11-02). Available at: http://aipl.arsusda.gov/reference/fertility/DPR_rpt.htm. Accessed June 11, 2003.

VanRaden, P. M., and A. J. Seykora. 2003. Net merit as a measure of lifetime profit: 2003 revision. AIPL Research Report: NM\$2 (7-03). Available at: http://aipl.arsusda.gov/reference/ nmcalc.htm. Accessed Dec 26, 2003.

Van Vleck, L. D. 1993. Selection Index and Introduction to Mixed Model Methods. CRC Press, Boca Raton, FL.

Veerkamp, R. F., J. K. Oldenbroek, H. J. Van Der Gaast, and J. H. J. Van Der Werf. 2000. Genetic correlation between days until start of luteal activity and milk yield, energy balance, and live weights. J. Dairy Sci. 83:577-583.

Veerkamp, R. F., E. P. C. Koenen, and G. De Jong. 2001. Genetic correlations among body condition score, yield, and fertility in first-parity cows estimated by random regression models. J. Dairy Sci. 84:2327-2335.

Weigel, K. A., T. J. Lawlor, Jr., P. M. Vanraden, and G. R. Wiggans. 1998. Use of linear type and production data to supplement early predicted transmitting abilities for productive life. J. Dairy Sci. 81:2040-2044.

Weigel, K. A., R. W. Palmer, and D. Z. Caraviello. 2003. Investigation of factors affecting voluntary and involuntary culling in expanding dairy herds in Wisconsin using survival analysis. J. Dairy Sci. 86:1482-1486.

Weigel, K. A., and R. Rekaya. 2000. Genetic parameters for reproductive traits of Holstein cattle in California and Minnesota. J. Dairy Sci. 83:1072-1080. 